\title{
Laboratory temperature-compensating calibration procedure for soil water content determination by reflectometry
}

\section{Calibração em laboratório para compensação de temperatura na determinação da umidade do solo via reflectometria}

\author{
André Tavares VASCONCELOS ${ }^{1}$; Rafael Cesar TIEPPO²; Rivanildo DALLACORT ${ }^{3}$; Adalberto SANTI ${ }^{4}$; \\ Maria Carolina da Silva ANDREA ${ }^{2}$ \\ ${ }_{1}^{1}$ Graduando em Agronomia, Universidade do Estado de Mato Grosso, andre.vasconcelos04@gmail.com \\ 2 autor para correspondência, Doutor em Ciências, Universidade do Estado de Mato Grosso, Departamento de Agronomia, \\ Rodovia MT - 358, Km 07, Jardim Aeroporto Tangará da Serra - MT - CEP: 78300-000, rafaelt@unemat.br \\ ${ }^{3}$ Doutor em Agronomia, Universidade do Estado de Mato Grosso, rivanildo@unemat.br \\ ${ }^{4}$ Doutor em Agricultura Tropical, Universidade do Estado de Mato Grosso, adalbertosanti@unemat.br \\ ${ }^{5}$ Doutora em Ciências, Universidade do Estado de Mato Grosso, mcarolesalq@gmail.com
}

Recebido em: 05-10-2017; Aceito em: 16-04-2018

\begin{abstract}
The water content reflectometer allows a temporal and spatial assessment in soil water dynamic. This work aimed to study the behavior of the sensor (CS616) for the period measurement in function to the temperature and soil water content. The tests were conducted at State University of Mato Grosso, Tangara da Serra municipality. We used PVC (polymerizing vinyl chloride) pipe to make six recipients $(0.1 \mathrm{~m}$ diameter and $0.4 \mathrm{~m}$ height) and filled them with soil. For each one of them a sensor CS616 and temperature sensor (K type) were allocate in a central position. The soil water content for each recipient were fitted to $0.00 ; 0.06 ; 0.11 ; 0.16 ; 0.22 ; 0.27 \mathrm{~m}^{3} \mathrm{~m}^{-3}$, and the samples were submitted to temperature gradient from 1.0 up to $40.0^{\circ} \mathrm{C}$. Data of temperature, and period response were recorded in a data logger. Notice that the temperature provides changes for period response values $(\mu \mathrm{s})$, and as greater the soil water content, as greater the temperature influence. From collected data, two models were fitted (linear and quadratic), and compared with manufacturer standard equations. For conditions in that study, the fitted quadratic model provide the best approach for the water soil content prediction.
\end{abstract}

Additional keywords: CS616, sensor, time domain reflectometry.

\begin{abstract}
Resumo
Os sensores de reflectometria permitem a avaliação temporal e contínua da dinâmica da água no solo. O objetivo deste trabalho foi avaliar a leitura (período) do sensor (CS616) em função do teor de água e da temperatura do solo, para a predição da umidade do solo. O estudo foi realizado na Universidade do Estado de Mato Grosso, no Câmpus Universitário de Tangará da Serra. Foram construídos seis tubos de PVC, nos quais foram acondicionados solo em seus interiores, sendo que em cada tubo foi instalado um sensor CS616 e um sensor de temperatura tipo "K". Posteriormente, condicionou-se o solo de cada tubo nas umidades volumétricas 0,$00 ; 0,06 ; 0,11$; 0,$16 ; 0,22$ e $0,27 \mathrm{~m}^{3} \mathrm{~m}^{-3}$, submetendo-os a um gradiente de temperatura de 1,0 até $40,0{ }^{\circ} \mathrm{C}$. Os valores de temperatura e do período foram registrados e armazenados em um sistema de aquisição de dados. Observou-se que a temperatura influencia nas mensurações do período $(\mu \mathrm{s})$, tendo maior influência à medida que se aumenta a umidade do solo. Uma vez constatada a referida influência, ajustou-se um modelo linear e outro quadrático que representassem o comportamento dos dados, comparando-os com as equações fornecidas pelo fabricante do sensor utilizado. Para as condições estudadas, a equação quadrática gerada neste trabalho gerou melhores resultados de predição da umidade volumétrica do solo em relação às demais.
\end{abstract}

Palavras-chave adicionais: CS616, reflectometria no domínio do tempo, sensor.

\section{Introduction}

The management of the water soil content is important in agricultural system production, it intends to avoid the deficit or excess of water in soil, providing ideal conditions for crops growth and decreasing irrigation costs (Freitas et al., 2013; Soares et al., 2015).

Usually there are two methods to obtain soil water content, direct and indirect. In the first one, the soil sample is extracted from the field to the lab for procedures, with no automation (standard method). In the second one, there is not necessity to extract soil sample from the field, providing conditions to automation and faster result obtaining (Gubiani et al., 2015; Souza et al., 2016).

Among indirect methods, the TDR (Time domain reflectometry) sensors is quick, simple, and robust way to obtain values of water soil content, and it provides a non-destructive method for soil samples (Topp et al.,1980; Skierucha et al., 2012). A disad- 
vantage of TDR is the relatively high cost, it is because the TDR needs a separate pulse and sampling unit. An alternative for the TDR is the CS616 water content reflectometer (WCR) sensors (Campbell Sci. Inc., Logan, UT), a type of a transmission line oscillator that operate in the time domain like TDR. The technology embodied in CS616 sensor is quite similar to time domain reflectometers (TDR), however does not needs a separate pulse and sampling unit (Kelleners et al. 2005).

Usually, sensor manufacturers provide standard equations to soil water content prediction, but several works show that results from that standard equations do not express the real soil conditions, because each soil has a specific features, requiring calibration models (Tommaselli \& Bacchi, 2001; Santos et al., 2010; Gonçalves et al., 2011).

At beginning, for water content soil prediction, there was an another point disregarded, it was the soil temperature (Topp et al., 1980). However, along the time, researches showed the temperature influence in water soil content prediction by TDR methods. Depending on temperature range, the predicted values of soil water content may achieve variation up to $10.0 \%$ (Mittelbach et al., 2012; Jung et al., 2013; Lu et al., 2015).

The objectives of this study was to analyze soil temperature influence for soil water content prediction by means TDR CS616 sensor and develop calibration equations to use with this sensor, in Dystrophic Red Latosol.

\section{Material and methods}

This work was carried out in the Laboratory of Agrometeorology located at the Center for Research, Studies and Agro-Environmental Development (CEPEDA) of the State University of Mato Grosso UNEMAT, Campus Tangará da Serra, 14 $4^{\circ} 39^{\prime} S$ and $57^{\circ} 25^{\prime} \mathrm{W}$, with an average altitude of $440 \mathrm{~m}$ (INMET National Institute of Meteorology).

Climate region according to Köppen is tropical wet (Aw), and the average precipitation is $1,830 \mathrm{~mm}$, in which two seasons are defined, one dry and one rainy, being from April to September and October to March, respectively (Dallacort et al., 2011). The soil was classified as a Dystrophic Red Latosol with a very clayey texture (Embrapa, 2013).

The procedures in this work were adapted by the methods proposed by Benson \& Wang, (2006) and Udawatta et al. (2011). At the experimental field of UNEMAT, Tangará da Serra Campus, deformed soil samples were collected at November of 2016, in subsequent layers: $0.0-0.2$ and $0.2-0.4 \mathrm{~m}$ to represent the soil profile. This soil has $415.0 \mathrm{~g} \mathrm{~kg}^{-1}$ of sand, $147.0 \mathrm{~g} \mathrm{~kg}^{-1}$ of silt and $438 \mathrm{~g} \mathrm{~kg}^{-1}$ of clay, (Inoue et al., 2010).

The soil samples from each layer were sifted by means sieve mash number 2 and placed in the oven $\left(105^{\circ} \mathrm{C}\right)$ to dry for 24 hours. After, pre- determined weights for each $5 \mathrm{~cm}$ increment of soil were packed to a desired bulk density of $1.1 \mathrm{Mg} \mathrm{m}^{-3}$ in a calibration cell. The calibration cell was a polyvinyl chloride (PVC) pipe with sealed bottoms, $0.4 \mathrm{~m}$ long and $0.1 \mathrm{~m}$ diameter. Note that to fill the calibration cell we followed the same sequence of soil layer from field. The height of profile soil inside of the calibrations cell was $0.3 \mathrm{~m}$. Avoiding preferential flow of water through the internal calibration cell walls, we applied paraffin. For each calibration cell, one CS616 sensor manufactured by Campbell Scientific (Campbell Sci, 2004), and one temperature type $K$ sensor were inserted. Both of them sensors were attached in a Data Logger for data registration. Gravimetric soil moisture percentage at the beginning and end were evaluated to assure no moisture loss during the study.

The water content in the sieved soil was adjusted by spraying the soil with the required amount of distilled water. It was assigned six soil water content levels $\left(0.00 ; 0.06 ; 0.11 ; 0.16 ; 0.22 ; 0.27 \mathrm{~m}^{3} \mathrm{~m}^{-3}\right)$. The value "zero" was not used to fit the model, because it has not a physic meaning. The top of the calibration cell was sealed with plastic after compaction to prevent evaporation. The calibration cells were conducted by cooling to warming, soil temperature range was from 1.0 up to $40.0^{\circ} \mathrm{C}$, and then measuring the period with the WCR (CS616). The calibration cell was cooled using a refrigerator and warmed using an oven.

The collected data was tidied and submitted to the analyses of variance and regression analysis, linear (eq. 1) and quadratic (eq. 2), to verify the behavior of the variables, at a $5 \%$ probability level using by means of R statistical software (R Core Team, 2017).

$\mathrm{Z}=\beta_{1} \mathrm{x}+\beta_{2} \mathrm{y}+\varepsilon$

$\mathrm{Z}=\beta_{1} \mathrm{x}+\beta_{2} \mathrm{y}+\beta_{3} \mathrm{x}^{2}+\beta_{4} \mathrm{y}^{2}+\varepsilon$

Fitted equations were compared with standard equations provided by sensor CS616 manufacturer (eq. 3 and eq. 4).

$\theta=-0.4677+0.0283 T$

$\theta=-0.0663-0.0063 T+0.0007 T^{2}$

Where: $\theta=$ volumetric water content $\left(\mathrm{m}^{3} \mathrm{~m}^{-3}\right)$; $\mathrm{T}=$ period (micro seconds; $\mu \mathrm{s}$ ).

Performance of fitted equations were assigned by the root mean square error (RMSE) (eq. 5).

RMSE $=\sqrt{\frac{\sum_{i=1}^{N}\left(O_{i}-P_{i}\right)^{2}}{n}} \frac{100}{\bar{O}}$

Where: $P_{i}$ stands for the predicted values, $O_{i}$ for the observed values and $\bar{O}$ for the observed mean values, $\mathrm{n}$ is the number of samples. 
Simulations are considered to be excellent with RMSE < $10 \%$, good between $10-20 \%$, fair between $20-30 \%$, and poor $>30 \%$ (Loague \& Green, 1991).

\section{Results and discussions}

Analyzing the temperature effect for period values, there was more period variation for greater values of volumetric water content. Notice that difference increases between the first and third quartile from 0.0 up to $0.27 \mathrm{~m}^{3} \mathrm{~m}^{-3}$ (Figure 1).

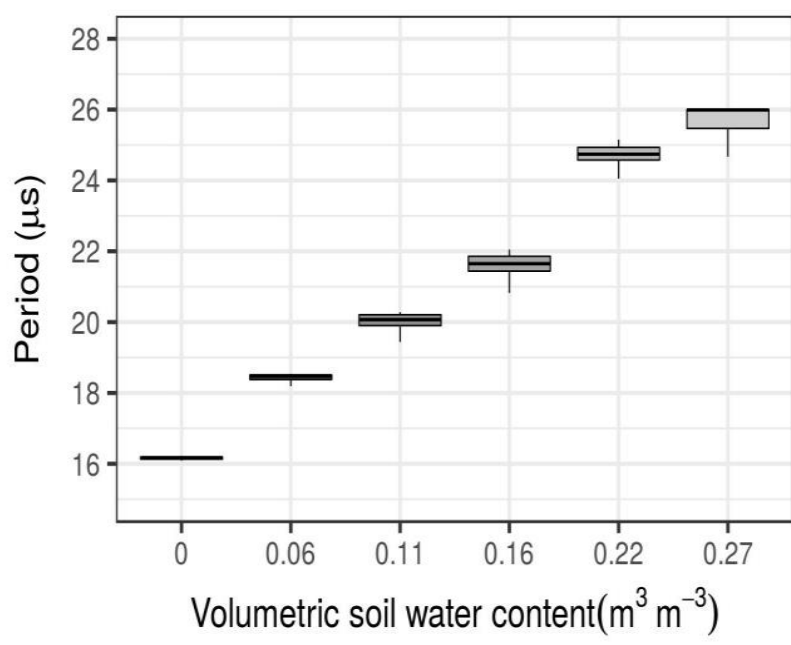

Figure 1 - Period for volumetric soil water content by means sensor (CS616) with temperature variation.

The sensibility behavior of period for temperatures is function of the water content level, and it may vary proportionally by changes in water soil content (Benson \& Wang, 2006; Lu et al., 2015). We found in this study an uniform response of the period for soil water content $0.0 \mathrm{~m}^{3} \mathrm{~m}^{-3}$ (Figure 2). However, regarding the water content raise from 0.06 up to $0.27 \mathrm{~m}^{3} \mathrm{~m}^{-3}$, specially between 5.0 and $20.0^{\circ} \mathrm{C}$, the period increases with increasing temperature. For temperatures greater than $20.0^{\circ} \mathrm{C}$, there is a trend to minimize the period ascendancy.

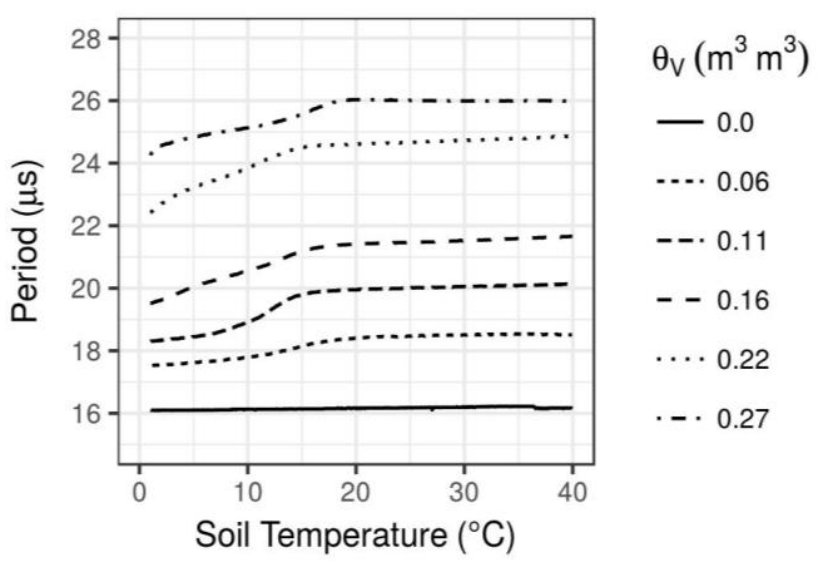

Figure 2 - Period as a function of soil temperature for six levels of soil volumetric water content by CS616 sensor.

Udawatta et al. (2011) observed a $0.725 \mu$ s increment of measured period originated from an increase in temperature from 5 to $40{ }^{\circ} \mathrm{C}$ by means of a TDR sensor. It indicates $0.013 \mathrm{~m}^{3} \mathrm{~m}^{-3}$ change in estimated soil water content by means of a manufacturerprovided quadratic equation. In another study, as temperatures increased between -22.0 and $36.0^{\circ} \mathrm{C}$, the period also showed increases, achieving a difference around 2.0 and $16.0 \mu \mathrm{s}$, for soil water content of 0.06 and $0.41 \mathrm{~m}^{3} \mathrm{~m}^{-3}$, respectively (Benson \& Wang, 2006). However, Carvalho et al. (2015) observed a non significant effect of temperature in period values for a range between 28.0 and $105.0^{\circ} \mathrm{C}$. We noticed that the period measured by means of CS616 sensor is more sensible to temperatures between 5 and $20^{\circ} \mathrm{C}$ (Figure 2). Thus, these findings indicate that soil-specific calibrations with temperature compensation should be developed to obtain better predictions of soil volumetric water content. Regarding analysis of variance for the period, and temperature variables, we found a significant effect for both of them at $1.0 \%$ level, for linear and quadratic model (Table 1).

Table 1 - Analysis of variance results for soil volumetric water content over period and temperature

\begin{tabular}{lcrcrc}
\hline \multirow{2}{*}{ Source of variation } & \multicolumn{5}{c}{ Linear regression model } \\
\cline { 2 - 6 } & FD & SS & MS & $\mathrm{F}$ & $\operatorname{Pr}(>\mathrm{f})$ \\
\hline Period $(\mu \mathrm{s})$ & 1 & 10.3719 & 10.3719 & 71585.6 & $2.210^{-16^{* *}}$ \\
Temperature $\left({ }^{\circ} \mathrm{C}\right)$ & 1 & 0.3363 & 0.3363 & 2528.2 & $2.210^{-16^{* *}}$ \\
Residues & 2097 & 0.3038 & 0.0001 & \\
\hline \multirow{2}{*}{ Source of variation } & \multicolumn{5}{c}{ Quadratic regression model } \\
\cline { 2 - 6 } & $\mathrm{FD}$ & $\mathrm{SS}$ & $\mathrm{MS}$ & $\mathrm{F}$ & $\operatorname{Pr}(>\mathrm{f})$ \\
\hline Period $(\mu \mathrm{s})$ & 2 & 103888 & 5.1944 & 60242.4 & $2.210^{-16^{* *}}$ \\
Temperature $\left({ }^{\circ} \mathrm{C}\right)$ & 2 & 0.4726 & 0.2363 & 2740.7 & $2.210^{-16^{* *}}$ \\
Residues & 2095 & 0.1806 & 0.0001 & & \\
\hline
\end{tabular}

ns No significant; "Significant at 5\% probability; "'Significant at $1 \%$ probability. 
Once both variables (period and temperature) were significant for soil volumetric water content, a linear and a quadratic model were fitted, equations 6 and 7 , respectively.

$$
\begin{aligned}
\theta= & -0.3745+0.02587 \mathrm{~T}-0.001181 \mathrm{C} \\
\theta= & -0.6292+0.05078 \mathrm{~T}-0.0005592 \mathrm{~T}^{2}- \\
& -0.003688 \mathrm{C}+0.00006044 \mathrm{C}^{2}
\end{aligned}
$$

Where: $\theta$ is volumetric water content $\left(\mathrm{m}^{3} \mathrm{~m}^{-3}\right), \mathrm{T}$ is the period $(\mu \mathrm{s})$ and $\mathrm{C}$ is the soil temperature $\left({ }^{\circ} \mathrm{C}\right)$.

Both of them fitted model achieved deterministic coefficient around $98.0 \%$, and all parameters were significant $(5.0 \%)$ by test-t. Comparing RMSE is possible to note that quadratic fitted model provides the best predictions values (Table 2).

Table 2 - Root mean square error (RMSE) of fitted and manufacturer equations

\begin{tabular}{lc} 
Equation & $\mathrm{RMSE}(\%)$ \\
\hline Linear fitted equation & 7.24 \\
Quadratic fitted equation & 5.58 \\
Manufacturer linear fitted equation & 14.87 \\
Manufacturer quadratic fitted equation & 21.23 \\
\hline
\end{tabular}

Regarding the method from Loague \& Green (1991), we found excellent score for both of them fitted equations (linear and quadratic), with a smooth advantage for the quadratic model. About manufacturer equations, the linear and quadratic equations provided a good and poor score, respectively.

Others factors may influence on period measurements by means CS616 sensor, especially the clay content (Udawatta et al., 2011; Ojo et al., 2015). We observed that the soil moisture instrument calibrations developed by the manufacturers for a general proposing are not always adaptable for use under field conditions. Therefore, it is important for scientists and irrigation professionals who use that newer sensors to control soil water content, proceed the calibration of the sensors to ensure good results (Logsdon, 2009).

\section{Conclusion}

The temperature variable influences in period measurements by means CS616 sensor. We found greater variations between temperatures 5.0 and $20.0^{\circ} \mathrm{C}$, and there is more period variation for greater values of volumetric water content. About the use of TDR sensor to predict soil water content, there is a recommendation to consider the temperature variable. For conditions in this study, the quadratic regression model was the best fitted model to describe the relationship between volumetric water content, period and temperature, with root mean square error of 5.58 .

\section{Acknowledgements} supporting.

We would like to thank FAPEMAT for

\section{References}

Benson CH, Wang X (2006) Temperature-compensating calibration procedure for water content reflectometers. 16p. Proc. TDR 2006, Purdue University, West Lafayette, Available at <https://engineering.purdue.edu/TDR/Papers> (accessed jun 02 2017).
Campbell Scientific Inc, CS (2004) Instruction Manual, CS616 and CS625 Water Content Reflectometers. Logan, UT, USA. 46p.

Carvalho TRA, Massaranduba WM, Fontenele SB, Landim RBTV, Mendonça LAR (2015) Ajuste de modelo para determinar a umidade em Neossolo Flúvico com uso de uma sonda Time Domain Reflectometry (TDR). Revista Agrarian 8(27): 57-63.

Dallacort R, Martins JA, Inoue MH, Freitas PSL, Coletti AJ (2011) Distribuição das chuvas no município de Tangará da Serra, médio norte do Estado de Mato Grosso. BrasilActa ScientiarumAgronomy 33(2): 193200. doi: 10.4025/actasciagron.v33i2.5838

Embrapa (2013) Empresa Brasileira de Pesquisa Agropecuária. Centro Nacional e Pesquisa em Solos. Sistema brasileiro de classificação de solos, Brasília. $353 p$.

Freitas RMO, Torres SB, Nogueira NW, Leal CCP, Farias RM (2013) Produção e qualidade de sementes de feijãocaupi em função de sistemas de plantio e estresse hídrico. Pesquisa Agropecuária Tropical 43(4): 370-376. doi: 10.1590/S1983-40632013000400009

Gonçalves ACA, Trintinalha MA, Tormena CA, Folegatti MV (2011) Influência da densidade do solo na estimativa da umidade em um nitossolo vermelho distroférrico, por meio da técnica de TDR. Revista Brasileira de Ciência Do Solo 35(5): 1551-1559.

Gubiani PI, Reinert DJ, Reichert, JM, Gelain NS (2015) Condição de contorno para calibração de reflectômetro usado para medição de água no solo. Ciência Rural 45(8): 1412-1417. doi: 10.1590/0103-8478cr20140907

Inoue MH, Santana DC, Oliveira Jr RS, Clemente RA, Dallacort R, Possamai ACS, Pereira KM (2010) Potencial de lixiviação de herbicidas utilizados na cultura do algodão em colunas de solo. Planta Daninha 28(4): 825-833. 
Jung S, Drnevich VP, Asce DM, Najm MRA (2013) Temperature corrections for time domain reflectometry parameters. Journal of Geotechinical and Geoenvironmental Engineering 139(5): 671-683. doi: 10.1061/(ASCE)GT.1943-5606.0000794

Kelleners, TJ, Seyfried MS, Blonquist JM, Bilskie J, Chandler DG (2005) Improved interpretation of water content reflectometer measurements in soils. Soil Science Society of America Journal 69(6): 1684. doi: 10.2136/sssaj2005.0023

Loague K, Green RE (1991) Statistical and graphical methods for evaluating solute transport models: Overview and application. Journal of Contaminant Hydrology 7(1-2): 51-73. doi: 10.1016/0169-7722(91)90038-3

Logsdon SD (2009) CS616 Calibration: Field versus Laboratory. Soil Science Society of America Journal 73(1). doi: 10.2136/sssaj2008.0146

Lu M, Kapilaratne J, Kaihotsu I (2015) A data-driven method to remove temperature effects in TDR-measured soil water content at a Mongolian site. Hydrological Research Letters 9(1):8-13. doi: 10.3178/hrl.9.8

Mittelbach H, Lehner I, Seneviratne SI (2012) Comparison of four soil moisture sensor types under field condition in Switzerland. Journal of Hydrology 430-431: 39-49. doi: 10.1016/j.jhydrol.2012.01.041

Ojo RE, Bullock PR, Fitzmaurice J (2015) Field Performance of Five Soil Moisture Instruments in Heavy Clay Soils. Soil Science Society of America Journal 79(1): 20. doi: 10.2136/sssaj2014.06.0250

R Core Team (2017) R: A Language and environment for statistical computing. Vienna, Austria. Avaiable in: http://www.R-project.org.
Santos MR dos, Zonta JH, Martinez MA (2010) Influência do tipo de amostragem na constante dielétrica do solo e na calibração de sondas de TDR. Revista Brasileira de Ciência do Solo 34(2): 299-308. doi: 10.1590/S0100-06832010000200003

Soares LA, Lima GS, Chaves LHG, Xavier DA, Fernandes PD, Gheyi HR (2015) Fitomassa e produção do girassol cultivado sob diferentes níveis de reposição hídrica e adubação potássica. Revista Brasileira de Engenharia Agrícola e Ambiental 19(4): 336342. doi: 10.1590/1807-1929/agriambi.v19n4p336-342

Souza CF, Silva CR, Soraes Junior A, Coelho EF (2016) Monitoramento do teor de água no solo em tempo real com as técnicas de TDR e FDR. Irriga Botucatu 1(1): 26-42.

Skierucha W, Wilczek A, Szypłowska A, Sławiński C, Lamorski K (2012) A TDR-Based Soil Moisture Monitoring System with Simultaneous Measurement of Soil Temperature and Electrical Conductivity. Sensors (Basel, Switzerland), 12(10): 13545-13566. doi: 10.3390/s121013545

Tommaselli JTG, Bacchi OOS (2001) Calibração de um equipamento de TDR para medida de umidade de solos. Pesquisa Agropecuária Brasileira 36(9): 11451154. doi: 10.1590/S0100-204X2001000900008

Topp GC, Davis JL, Annan AP (1980) Electromagnetic determination of soil water content: Measurements in coaxial transmission lines. Water Resources Research 16(3): 574-582. doi: 10.1029/WR016i003p00574

Udawatta RP, Anderson SH, Motavalli PP, Garrett HE (2011) Calibration of a water content reflectometer and soil water dynamics for an agroforestry practice. Agroforestry Systems 82(1): 61-75. doi: 10.1007/s10457010-9362-3 